\title{
Inhibitory Effect of a Human T Cell Hybrid Factor on Both Cell Growth and Mixed Lymphocyte Reactivity

\author{
Correlation with Class II Molecule Expression
}

\author{
Massimo Trucco, Sara Shaw, and Robert Korngold \\ The Wistar Institute of Anatomy and Biology, Philadelphia, Pennsylvania 19104
}

\begin{abstract}
We recently reported the biological activity and some of the biochemical characteristics of a factor produced by a human $T$ cell hybrid clone able to block hematopoietic progenitor cell proliferation. This $85-\mathrm{kD}$ protein factor, which we have termed colony-inhibiting lymphokine (CIL), has growth regulatory activity on bone marrow precursors bearing Ia (class II) antigens of either granulocytic-monocytic (CFU-GM) or erythroid lineage (BFUE and CFU-E). Experiments aimed to investigate the specificity of the inhibitory effect on hematopoietic progenitor cell growth suggested that the expression of HLA-DR surface antigens was required on the target cells. We describe in this communication how $\mathrm{DR}^{+}$cell lines ceased dividing after a few days of culture in the presence of $\mathrm{CIL}$, whereas $\mathrm{DR}^{-}$cell lines were completely unaffected. The increased DR expression on the ML3 cell surface, mediated by the activity of the gamma interferon (IFN $\gamma$ ), increases the sensitivity to the growth inhibition factor of the ML3 cell line. To verify the hypothesis that the DR antigens might serve as receptors for the factor, enabling it also to interfere in the immune response, we tested CIL in a mixed lymphocyte reaction (MLR), one of the best known in vitro Ia antigen-dependent $\mathrm{T}$ cell-mediated immune responses. CIL is able to block major histocompatibility complex-allogeneic MLR both in human and mouse systems. The data indicate that CIL recognizes a nonpolymorphic structure (presumably on all Ia molecules) presented by stimulator cells of either species, and thereby interferes with specific interactions between stimulator and responder cells. Blocking of the alloantigen stimulation stage is also indicated, since CIL is effective only if added to the culture medium during the first $48 \mathrm{~h}$ of the MLR. Finally, mouse monoclonal anti-DR antibodies are able to sharply reduce CIL activity on sensitive $\mathrm{DR}^{+}$cell lines. CIL may act physiologically as a multifunctional mediator in a complex network that links regulation of bone marrow differentiation and the generation of immune responses.
\end{abstract}

\section{Introduction}

Hematopoiesis is a dynamic process involving the balanced action of both enhancing and inhibiting regulator cells that act either directly or through soluble mediators. Among the best known enhancing factors are the granulocytic-monocytic colony-

Address reprint requests to Dr. Massimo Trucco, The Wistar Institute, Philadelphia, PA 19104.

Received for publication 26 December 1984 and in revised form 8 April 1985.

J. Clin. Invest.

(c) The American Society for Clinical Investigation, Inc.

$0021-9738 / 85 / 09 / 1032 / 10 \quad \$ 1.00$

Volume 76, September 1985, 1032-1041 stimulating factor $(\mathrm{CSF})^{1}(1-3)$, and the burst-promoting activity (BPA) (4) factor, which, in association with erythropoietin, is able to stimulate the growth of erythroid progenitors in vitro (5). Inhibitory factors, most of which are leukocyte products, include lactoferrin (6), prostaglandin $\mathrm{E}(7)$, acidic isoferritin (8), and transferrin (9). In most of the feedback systems described, the Ia (class II) surface antigenic system appears to play a role in the proliferative events in the marrow (10-12). Both myeloid (colony-forming units granulocytic-monocytic [CFU-GM]) and erythroid progenitor cells (burst-forming units-erythroid and colony-forming units-erythroid [BFU-E and CFU-E]) express Ia antigenic determinants on their surfaces, although these progenitor cells appear to be generated from pluripotent stem cells lacking Ia antigens $(13,14)$. Only $\mathrm{Ia}^{+}$cells seem to be targets of these enhancing and inhibitory factors. It is also known that the in vitro growth of erythroid precursors can be enhanced by coculture with normal $\mathrm{T}$ cells (15). The growth-enhancing effect of normal $\mathrm{T}$ cells, however, was shown to be the competitive outcome of at least two functionally distinct subpopulations: one that enhances burst formation, and one that limits it (15). There is evidence that the inhibitory effect of the latter $T$ cell subset on BFU-E growth may involve the Ia molecule, since this inhibitory action seems genetically restricted to cells that share expression of at least one HLA-DR (Ia) antigen (16). Whether these effects are mediated by direct interactions of $T$ cells with BFU-E or by indirect actions involving auxiliary cells or $T$ cell factors remains to be determined.

The role of the Ia (class II) antigen system is certainly better characterized in immune responsiveness. Again, the phenomenon involves the balanced action of regulator cells with opposite characteristics, i.e., helper and suppressor functions, both of which are known to be Ia-restricted at least in controlling the production of specific antibodies by $B$ cells $(17,18)$. Specific helper and suppressor factors produced by normal $\mathrm{T}$ cells or $\mathrm{T}$ cell hybridomas, many of which are restricted to specific recognition of antigen in conjunction with major histocompatibility complex (MHC) (class II) components (19), also have been well documented, particularly in the mouse.

We were interested in determining whether a factor secreted by $T$ lymphocytes would regulate not only the growth of bone marrow progenitor cells, but also the activity of $T$ helper cells

1. Abbreviations used in this paper: BFU-E, burst-forming units-erythroid; BPA, burst-promoting activity; CFU-E, colony-forming units-erythroid; CFU-GM, colony-forming units granulocytic-monocytic; CIL, colonyinhibifing lymphokine; CSF, colony-stimulating factor, E, erythrocytes; EA7S, IgG-sensitized ox E; EBV, Epstein-Barr virus; FcR, receptor for the Fc domain of IgG; FCS, fetal calf serum; FITC, fluorescein isothiocyanate; $\left[{ }^{3} \mathrm{H}\right] \mathrm{TdR},\left[{ }^{3} \mathrm{H}\right]$ thymidine; IFN, interferon; IFN $\alpha$, alpha interferon; IFN $\gamma$, gamma interferon; MLR, mixed lymphocyte reaction; MHC, major histocompatibility complex; MT1 SN, MT1 supernatant; PAGE, polyacrylamide gel electrophoresis; TDL, thoracic duct lymphocytes. 
involved in immunoresponsiveness, by affecting the expression or recognition of the same cell surface molecules, i.e., the Ia antigens. For this purpose, we used a human factor, termed colony-inhibiting lymphokine (CIL), from the supernatant of a cloned T cell hybrid (designated MT1) (20). This protein factor has growth regulatory activity on bone marrow cells bearing Ia antigens (20). As presented in this report, it also exerts a regulatory effect on the proliferation of Ia-positive lymphoblastoid cell lines. This positive correlation between Ia expression and CIL growth inhibition suggested that the factor might also be capable of regulating immune responses. To test this hypothesis, we examined the effect of CIL in HLA-disparate mixed lymphocyte reactions (MLRs). CIL activity completely blocked these allo-responses by perturbing specific cell-to-cell interactions rather than eliciting a nonspecific cytotoxic effect. CIL activity did not appear to be restricted to any particular class II polymorphic determinant, nor did it appear to be species-specific, since the factor was also active in murine $\mathrm{H}-2$ allogeneic MLR experiments. Finally, we present more direct evidence for the role of the Ia molecules as targets for factor-mediated regulation.

\section{Methods}

CIL production. MT1 clone has been derived from one of the seven hypoxanthine-azaserine-resistant cell colonies detected $2 \mathrm{wk}$ after fusion between the 6-thioguanine-resistant mutant (6TM) of the Jurkat human T-lymphoma cell line and phytohaemagglutinin-stimulated peripheral blood lymphocytes from a healthy female volunteer in the presence of polyethylene glycol 1500 (21). MT1 clone secretes in culture medium a factor (CIL) able to inhibit haematopoietic progenitor cell proliferation (20). MT1 clone cells were cultured in complete medium (RPMI 1640 medium containing $10 \%$ fetal calf serum [FCS], $100 \mu \mathrm{g}$ streptomycin, $100 \mathrm{U}$ penicillin, and $1 \mathrm{mM}$ L-glutamine), and stocks of supernatant prepared using the same cell concentration $\left(5 \times 10^{5} / \mathrm{ml}\right)$ and the same harvesting day (day 3 after last feeding) were used as the source of CIL factor. MTI cells cultured in synthetic medium (RPMI 1640, $100 \mu \mathrm{g}$ streptomycin, $100 \mathrm{U}$ penicillin, $2 \mathrm{mM}$ L-glutamine, $3 \times 10^{-8}$ selenium dioxide, $0.015 \mathrm{M}$ Hepes, $\mathrm{pH} 7.2,5 \mu \mathrm{g} / \mathrm{ml}$ insulin, $5 \mu \mathrm{g} / \mathrm{ml}$ transferrin) were also able to secrete the factor. Supernatant from $6 \mathrm{TM} T$-lymphoma cells (20) originally used to construct the MT1 hybrid cell and cultured under the same conditions as MT1 was used as the control.

Human cell lines. The T cell lymphoma lines Jurkat and Molt 4, the promyelocytic leukemic cell line ML3, the Epstein-Barr virus (EBV)transformed B cell lines WT18, WT20, WT46, WT50, WT51, WT52, and the Burkitt lymphomas, Daudi and Raji, were maintained in culture in complete medium in a $5 \% \mathrm{CO}_{2}$ humidified incubator at $37^{\circ} \mathrm{C}$. HLA typing of these cell lines has been described (21).

Human peripheral blood lymphocytes (PBL). PBL cells from normal donors were HLA-A, $-\mathrm{B}$, and $-\mathrm{C}$ serotyped with highly selective reagents in the standard National Institutes of Health two-stage complementdependent lymphocytotoxicity technique at room temperature. HLADR determinants were typed on B cell-enriched suspensions using the same method adapted for B cells (21).

Human MLR. Peripheral blood mononuclear cells from different HLA-typed donors were challenged in a MLR (22) using $1 \times 10^{5}$ responder cells purified by Ficoll-Hypaque density centrifugation and 2 $\times 10^{5}$ irradiated cells $\left(4,000 \mathrm{rad}\right.$ from a ${ }^{137} \mathrm{Cs}$ source $)$ as stimulators in a $0.2 \mathrm{ml}$ final volume of RPMI 1640 medium supplemented with $10 \%$ responder autologous serum, $2 \mathrm{mM}$ L-glutamine, $100 \mu \mathrm{g}$ streptomycin, and $100 \mathrm{U}$ penicillin. Responder and stimulator cells were seeded together in 96-well flat-bottomed microtiter plates (Costar 3596 [Costar, Cambridge, MA]), labeled for $12 \mathrm{~h}$ after $5 \mathrm{~d}$ of culture with $0.25 \mu \mathrm{Ci}$ $\left[{ }^{3} \mathrm{H}\right]$ thymidine $\left(\left[{ }^{3} \mathrm{H}\right] \mathrm{TdR}\right)(2 \mathrm{Ci} / \mathrm{mmol}$ specific activity [Amersham Corp., Arlington Heights, IL]), harvested onto fiber filters, dried, and assayed in a Beckman beta spectrophotometer for $\left[{ }^{3} \mathrm{H}\right] \mathrm{TdR}$ incorporation
(Beckman Instruments, Palo Alto, CA). For inhibition experiments, appropriate wells received $22 \mu \mathrm{l}$ of MT1 supernatant dilutions, while controls were given an equal volume of control medium.

Inhibition test of human cell lines. Cells were seeded at 1,250 cells per well of a microtiter plate (Costar 3596) in $200 \mu \mathrm{l}$ of medium. For each cell line, comparisons were made between groups of six wells containing MT1 supernatant dilutions and those containing control supernatant dilutions. The cultures were harvested on the respective days of culture and evaluated as described above. Cell growth was also monitored by microscopic counting of the cells on alternate days after a Trypan blue dye-exclusion test. For this purpose the different cell lines were cultured in duplicate flasks and fed on alternate days by replacing twothirds of the cell suspension with normal medium containing either MT1 or control supernatant. Where the effect of anti-DR monoclonal antibodies was studied (described below) on CIL-treated cell lines, a fixed quantity of antibodies $(5 \mu \mathrm{g} / 100 \mu \mathrm{l}$ of culture medium) and dilutions of the factor were added simultaneously.

Mice. Male CBA/J, (C57Bl/6xCBA/J)F1 (B6CB), DBA/2, and female SJL mice were purchased from Jackson Laboratory (Bar Harbor, ME). B10.S(9R) mice were originally obtained from Dr. C. David (Mayo Clinic, Rochester, $\mathrm{MN}$ ) and bred in our colony. All mice were used at 8-12 wk of age.

Murine cells. CBA thoracic duct lymphocytes (TDL) were used as responder cells both because of their high viability $(>99 \%)$ and their reliably efficient responses. These cells were obtained from cannulated mice (23) and collected 4-20 h after the initiation of drainage. Stimulator cells from the spleens of appropriate mice were resuspended in media by a Ten Broeck tissue grinder (Thomas Scientific, Swedesboro, NJ), washed, and irradiated (1,500 rad) with a ${ }^{137} \mathrm{Cs}$ gamma source. The medium for all murine experiments was Iscove's modified Dulbecco's medium (Gibco Laboratories, Grand Island, NY) supplemented with $10 \%$ fetal bovine serum (HyClone Inc., Logan, UT) and $50 \mathrm{mg} / \mathrm{ml}$ of gentamycin sulfate (M.A. Bioproducts, Walkersville, MD).

Murine MLR. Responder CBA TDL $\left(2.5 \times 10^{5}\right.$ cells in $100 \mu \mathrm{l}$ vol $)$ were mixed with irradiated spleen stimulator cells $\left(5 \times 10^{5}\right.$ cells in 100 $\mu \mathrm{l} \mathrm{vol}$ ) in quadruplicate wells of a microtiter plate (Costar 3596). For inhibition experiments, appropriate wells received MT1 supernatant dilutions or control medium as described for human cell MLRs.

Monoclonal antibodies. Mouse monoclonal antibodies directed against the common part (S1.19/9, B33.1), or the allotypic site (MT2, E3.15/4) of the HLA-DR molecule has been described previously (21, 24). $S 1.34 / 28$ is a monomorphic monoclonal antibody directed against the common part of the HLA-A, -B, and -C molecules $(21,25)$. All of the monoclonal antibodies were affinity-purified on a Protein A column (26) and resuspended in phosphate-buffered saline (PBS) to a concentration of $2 \mathrm{mg} / \mathrm{ml}$. Monoclonal antibodies B36.1 (anti-T1), B67.1 (antiT11), and B33.1 (anti-DR) were from Dr. G. Trinchieri (The Wistar Institute of Anatomy and Biology, Philadelphia, PA) (27). Anti-T3 (antileu 4) was from Becton-Dickinson \& Co., Mountainview, CA, and antiT4 (OKT4) and anti-T8 (OKT8) were from Ortho Pharmaceuticals (Raritan, NJ). ${ }^{125}$ I direct labeling of monoclonal antibodies was performed using the classical chloramine-T method with small modifications as published in reference 28 .

Flow cytofluorometric analysis. Target cells $\left(2-3 \times 10^{5}\right)$ were treated with $20 \mu \mathrm{l}$ of the monoclonal antibodies at appropriate dilutions, incubated at room temperature for $30 \mathrm{~min}$, and washed three times. The cells were then incubated in $20 \mu \mathrm{l}$ of fluorescein isothiocyanate (FITC)conjugated goat anti-mouse $\mathrm{F}\left(\mathrm{ab}^{\prime}\right)_{2}$ antiserum (Cappel Laboratories, Cochranville, PA). Control cultures were treated with the Ig of the parental mouse myeloma $(\times 63)$, or with an irrelevant monoclonal antibody of the same isotype. In the experiment shown in Fig. 1, mouse monoclonal antibodies directly labeled with FITC were used. An Ortho Cytofluorograf System 50H (Ortho Diagnostics Systems, Inc., Westwood, MA) connected to an MP/20 microprocessor (Data General, Westboro, MA) was used for analysis of the fluorescent cells. The fluorescence signals were assigned into 200 channels by a pulse height analyzer, using a linear scale. The fluorescence channel was used at the threshold at which $99 \%$ of the cell population treated with control Ig and FITC-anti-mouse Ig antibodies 
were negative. Fluorescence intensity within each experiment was evaluated by determining the mean fluorescence channel of positive cells.

Interferon. 1,000 $\mathrm{U}$ of either affinity-purified human gamma interferon (IFN $\gamma)\left(10^{6} \mathrm{U} / \mathrm{mg}\right.$ protein) or ultra-pure human alpha interferon (IFN $\alpha)\left(1.48 \times 10^{8} \mathrm{U} / \mathrm{mg}\right.$ protein) were added to $3-5 \times 10^{5}$ cells resuspended in $1 \mathrm{ml}$ of culture medium. IFNs were obtained from Interferon Sciences, Inc. (New Brunswick, NJ).

Chromosome analysis. Chromosome preparations were produced according to standard techniques (29). Approximately $10^{6}$ cells $/ \mathrm{ml}$ were placed in basic growth medium containing $0.5 \mu \mathrm{g} / \mathrm{ml}$ colcemid (Sigma Chemical Co., St. Louis, MO) for $45 \mathrm{~min}$ at $37^{\circ} \mathrm{C}$. The cells were then hypotonically treated for $30 \mathrm{~min}$ at $37^{\circ} \mathrm{C}$ and fixed at room temperature with methanol and acetic acid (3:1). The cell suspension was then placed on a slide, Giemsa stained, and metaphase spreads were examined microscopically.

Rosetting tests. Ox erythrocytes (E) and ox erythrocytes sensitized with rabbit IgG anti-ox E (EA7S) (Cappel Laboratories) were used as the indicator system for the receptor for the Fc domain of IgG (FcR). E rosetting and EA7S (FCR)-rosetting assays were performed as described (30). At least 300 cells were counted per sample.

Gel filtration. Supernatant of MT1 cells cultured in synthetic medium was passed through a $0.9 \times 55-\mathrm{cm}$ Sephadex G-100 (Pharmacia Fine Chemicals, Piscataway, NJ) column at a flow rate of $2 \mathrm{ml} / \mathrm{h}$, in the presence of $50 \mathrm{mg} /$ liter of polyethylene glycol 6000 (BDH Chemicals, Poole, England) in PBS. Inhibitory activity was eluted in fractions corresponding to $85,000 \mathrm{~mol} \mathrm{wt}$. These fractions were pooled and tested at the appropriate reconstituted dilutions for inhibitory activity in a 6-d human MLR.

\section{Results}

Inhibitory effect of CIL on the growth of human cell lines. The supernatant from a human T cell hybrid clone (MT1), the antigenic phenotype of which is given in Table I, was used to investigate the inhibitory effect of CIL on the growth of human cell lines. A panel of different cell lines was assayed over a 2-wk period for proliferation in the presence of either clone MT1 or control supernatant (Table II). Data from $\left[{ }^{3} \mathrm{H}\right] \mathrm{TdR}$ incorporation tests were confirmed by direct counting of viable cells as determined by dye exclusion (not shown). $\mathrm{DR}^{-}$cells such as Molt 4 and Jurkat were completely unaffected by the presence of the CIL factor. The growth of ML3, a human promyelocytic leukemic cell line, was partially inhibited by the presence of the MT1 supernatant at the beginning of the test period, but the cells recovered and grew well after that. ML3 cells were found to include a very low percentage of $\mathrm{DR}^{+}$cells. By contrast, all of the $\mathrm{DR}^{+}$cell lines, such as the EBV-transformed lymphoblastoid cells (WT18, WT20, WT51, and WT52) and the Burkitt lymphomas (Daudi and Raji), ceased dividing after a few days of culture in the presence of CIL. After a period of between 6 and $10 \mathrm{~d}$, depending on the cell line, all of the CIL-sensitive cells in the cultures treated with the factor had died, whereas the controls grown in the presence of $10 \%$ control supernatant continued normal growth.

Effect of CIL on ML3 cells treated with IFN $\gamma$ or IFN $\alpha$. To test the hypothesis that DR-expression correlated with the inhibitory effect of CIL, we tested ML3 cells with the factor in the presence of IFN $\gamma$ (Table III), which is known to enhance the quantitative expression of DR antigen on the cell surface. As expected, CIL treatment alone reduced ML3 cell growth in the first $2 \mathrm{~d}$ of culture, after which the cells grew well. This observation was confirmed by the stable percent inhibition calculated on days 4-6 (e.g., 52,58 , and $51 \%$ at $0.1 \%$ MT1 supernatant dilution). Treatment with IFN $\gamma$ reduced the growth rate of the ML3 cells, but also enhanced CIL activity. The percent inhibition obtained in IFN $\gamma$-treated ML3 cells vs. those not treated with IFN $\gamma$, upon addition of MT1 supernatant, differed significantly. The difference was evident on days 4 and 5 of cell culture, when the inhibition due to CIL alone ranged from 51 to $58 \%$ (at $0.1 \%$ MT1 dilution), while that due to IFN $\gamma$ reached $96-97 \%$. At a $0.01 \%$ MT1 dilution, the difference was even more striking, i.e., $38-31$ vs. $87-97 \%$ of untreated and IFN $\gamma$-treated cells, respectively. Note that percent inhibitions for the culture incubated with MT1 supernatant only were calculated using as $0 \%$ inhibition the $\left[{ }^{3} \mathrm{H}\right] \mathrm{TdR}$ incorporation of untreated ML3 cells, whereas incorporation by cells treated only with IFN $\gamma$ was used as the $0 \%$ inhibition to calculate the inhibition of cultures treated with both IFN $\gamma$ and CIL. The reduction of cell growth due to IFN $\gamma$, per se, was also calculated, using the incorporation of untreated cells as $0 \%$ inhibition, and the percentage given in parentheses in Table III. To rule out the possibility that IFN $\gamma$ and CIL were acting synergistically independently of DR expression, we also tested ML3 cells that had been pretreated for $3 \mathrm{~d}$ with IFN $\gamma$, washed three times, and then seeded in the presence of CIL only. Increased DR expression as a result of IFN $\gamma$ treatment was verified by cytofluorometry using a FITCanti-DR monoclonal antibody (Fig. 1). The IFN $\gamma$-pretreated ML3 cells were more sensitive to the CIL activity than the cells not treated with IFN $\gamma$. Inhibition on day 4 for the IFN $\gamma$-pretreated cells was 77 and $43 \%$ vs. 52 and $38 \%$ for the untreated cells, and 89 and $78 \%$ vs. 58 and $31 \%$ on day 5 at the two $(0.1$ and 0.01 ) CIL dilutions tested, respectively. Percentage inhibition of IFN $\gamma$-pretreated cells, exposed to CIL on day 4 for the first time, can also be compared to percent inhibition of untreated cells at the beginning of their period of CIL exposure, i.e., when the cell targets are more CIL sensitive (10 and $15 \%$ vs. 77 and

Table I. Genotypic and Phenotypic Characteristics of MTI Clone

\begin{tabular}{|c|c|c|c|c|c|c|c|c|c|c|}
\hline & \multirow{2}{*}{$\frac{\text { Genotype }}{\text { Chromosomes* }}$} & \multicolumn{9}{|c|}{ Phenotype } \\
\hline & & T Ag: & 1 & 3 & 4 & 8 & 11 & SE§ & FC & HLA" \\
\hline Clone MT1 & $59(43-81)$ & & 35.6 & 1.2 & 94.6 & 1.2 & 0.4 & $<5$ & $<5$ & $\mathrm{Al}, 31$ \\
\hline
\end{tabular}

\footnotetext{
* Chromosome analysis was done according to standard techniques described in Methods on MT1 clone cells after 10 mo of continuous culture. 59 is the modal chromosome number from 100 metaphases counted. ₹ T Ag: reactivity with monoclonal anti-human $\mathrm{T}$ cell antigens (T Ag) (39) antibodies was determined by quantitative flow cytometry. Values are a percentage of positive cells. Sources of monoclonal antibodies are given in Methods. $\S \mathrm{E}$ rosetting (SE) and EA7S (FcR) rosetting (FC) assays were performed as described in Methods. Less than five cells out of 100 were rosette-positive. At least 300 cells were counted. "HLA typing was done using highly selective alloantisera in complement-dependent lysis. Alleles at the $\mathrm{B}, \mathrm{C}$, and DR loci were not detectable.
} 
Table II. Inhibitory Effect of Clone MTI Supernatant on the Growth of Human Cell Lines

\begin{tabular}{|c|c|c|c|c|c|c|c|c|c|c|c|c|c|}
\hline \multirow[b]{3}{*}{ Cell line* } & \multirow{2}{*}{\multicolumn{4}{|c|}{ HLA typingf }} & \multirow[b]{3}{*}{$\% \mathrm{DR}^{+} \S$ cells } & \multirow[b]{3}{*}{ MTI SN 10\% } & \multicolumn{7}{|c|}{$\left[{ }^{3} \mathrm{H}\right] \mathrm{TdR}^{\prime \prime}$} \\
\hline & & & & & & & \multicolumn{7}{|c|}{ Incorporation $\left(\mathrm{cpm} \times 10^{-3}\right)$ on day } \\
\hline & A & B & C & DR & & & 1 & 3 & 5 & 7 & 9 & 11 & 13 \\
\hline \multirow[t]{2}{*}{ Jurkat } & 1,31 & - & - & - & 0.7 & - & 0.2 & 0.6 & 1.0 & 3.7 & 2.1 & 6.3 & 11.3 \\
\hline & & & & & & + & 0.1 & 0.2 & 1.0 & 2.2 & 1.9 & 7.2 & 13.2 \\
\hline \multirow[t]{2}{*}{ Molt 4} & 1,10 & - & - & - & 1.5 & - & 0.2 & 0.4 & 0.9 & 2.9 & 2.9 & 2.3 & - \\
\hline & & & & & & + & 0.2 & 0.2 & 1.5 & 3.1 & 4.2 & 5.1 & - \\
\hline \multirow[t]{2}{*}{ ML3 } & ND & ND & ND & - & 23.5 & - & 0.4 & 8.8 & 19.5 & 32.8 & 40.3 & 33.4 & 70.2 \\
\hline & & & & & & + & 0.6 & 4.2 & 10.0 & 7.2 & 14.4 & 13.2 & 51.2 \\
\hline \multirow[t]{2}{*}{ WT 18} & 2 & 27 & 2 & 2 & 99.0 & - & 3.2 & 7.3 & 11.5 & 11.6 & 33.6 & 33.2 & - \\
\hline & & & & & & + & 0.6 & 0.9 & 0.6 & 0.7 & 0.6 & 0.4 & - \\
\hline \multirow[t]{2}{*}{ WT 20} & 30 & 18 & 5 & 3 & 94.0 & - & 2.6 & 3.3 & 7.9 & 11.7 & 10.2 & 16.8 & - \\
\hline & & & & & & + & 0.7 & 0.5 & 1.8 & 0.8 & 1.0 & 0.6 & - \\
\hline \multirow[t]{2}{*}{ WT 51} & 9 & 14 & - & 4 & 97.0 & - & 4.9 & 16.3 & 12.9 & 88.4 & 96.4 & 76.1 & 86.9 \\
\hline & & & & & & + & 1.4 & 1.6 & 2.5 & 1.5 & 1.2 & 0.5 & 0.7 \\
\hline \multirow[t]{2}{*}{ WT 52} & 11 & 22 & 3 & w6 & 99.0 & - & 4.9 & 10.9 & 18.5 & - & - & 34.3 & 16.3 \\
\hline & & & & & & + & 0.8 & 1.1 & 1.1 & - & - & 0.9 & 0.8 \\
\hline \multirow[t]{2}{*}{ Raji } & ND & ND & ND & $5, w 6$ & 92.0 & - & 1.7 & 5.7 & 28.4 & 38.1 & 40.8 & 24.5 & 44.4 \\
\hline & & & & & & + & 0.8 & 1.2 & 0.8 & 1.5 & 0.8 & 0.5 & 0.8 \\
\hline \multirow[t]{2}{*}{ Daudi } & - & - & - & w6 & 94.0 & - & 0.7 & 1.1 & 1.5 & 2.5 & 2.7 & 13.2 & 24.7 \\
\hline & & & & & & + & 0.3 & 0.5 & 0.3 & 0.4 & 0.4 & 0.3 & 0.1 \\
\hline
\end{tabular}

* 1,250 cells/well were seeded in Costar 3596 96-well trays in $200 \mu$ l of complete medium. For each cell line, six wells with $10 \%$ control supernatant $(-)$ and six wells with $10 \%$ MT1 supernatant $(+)$ were compared. $\ddagger-$ indicates serologically undetectable cell surface antigen at the particular locus. ND, not done. All of the EBV-transformed cell lines used are from homozygous donors so that only one allele at each locus is detected. $\S$ Based on reactivity with the monomorphic monoclonal antibody S1.19/9 directed against the HLA-DR antigen as determined by indirect immunofluorescence using the Ortho Cytofluorograf $50 \mathrm{H}$. "Cultures were incubated overnight with $\left[{ }^{3} \mathrm{H}\right] \mathrm{TdR}$ and incorporation (mean cpm values) determined on the respective days in culture. Cell growth was also monitored by counting the cells in a dye exclusion test on alternate days.

Table III. Effect of MTI Supernatant on ML3 Cells Treated with IFN or IFNa

\begin{tabular}{|c|c|c|c|c|c|c|}
\hline \multirow[b]{2}{*}{ Cell } & \multirow[b]{2}{*}{ Cultured in presence of } & \multicolumn{5}{|c|}{ Percentage of inhibition of $\left[{ }^{3} \mathrm{H}\right] \mathrm{TdR}$ incorporation on day: } \\
\hline & & 2 & 3 & 4 & 5 & 6 \\
\hline \multirow[t]{3}{*}{ ML3 } & Medium & $0(19,922)^{*}$ & $0(25,450)$ & $0(71,608)$ & $0(82,512)$ & $0(7,440)$ \\
\hline & MT1 SN 0.1\% & 10 & 68 & 52 & 58 & 51 \\
\hline & $0.01 \%$ & 15 & 49 & 38 & 31 & 48 \\
\hline \multirow[t]{3}{*}{ ML3 } & $\operatorname{IFN} \gamma(1,000 \mathrm{U} / \mathrm{ml})$ & $0(12) \ddagger$ & $0(9)$ & $0(40)$ & $0(45)$ & $0(30)$ \\
\hline & $\mathrm{IFN} \gamma+\mathrm{MT} 1 \mathrm{SN} 0.1 \%$ & 34 & 76 & 96 & 97 & 98 \\
\hline & $0.01 \%$ & 17 & 74 & 87 & 97 & 98 \\
\hline \multirow[t]{2}{*}{ ML3 } & $\operatorname{IFN} \gamma(1,000 \mathrm{U} / \mathrm{ml})$ & & MT1 SN 0.1\% & 77 & 89 & \\
\hline & $3 \mathrm{~d}$ in culture & & $0.01 \%$ & 43 & 78 & \\
\hline \multirow[t]{3}{*}{ ML3 } & $\operatorname{IFN} \alpha(1,000 \mathrm{U} / \mathrm{ml})$ & & $0(37)$ & $0(23)$ & $0(13)$ & \\
\hline & $\mathrm{IFN} \alpha+\mathrm{MT} 1 \mathrm{SN} 0.1 \%$ & & 71 & 54 & 56 & \\
\hline & $0.01 \%$ & & 44 & 41 & 34 & \\
\hline
\end{tabular}

ML3 cells were seeded (5,000 cells/well) in Costar 3596 96-well trays in $200 \mu$ l of complete medium. Cultures were incubated overnight with $\left[{ }^{3} \mathrm{H}\right] \mathrm{TdR}$ and incorporation determined on the respective days in culture. Median cpm values from three wells supplemented with $10 \%(22 \mu \mathrm{l})$ of medium were compared with median values from wells supplemented with MT1 supernatant ( $\mathrm{SN})$ at different dilutions. Triplicate samples were used for each dilution tested. ${ }^{*} \mathrm{cpm}$ values in parentheses were considered as $100 \%$ cell growth or 0 inhibition to calculate the inhibition rate for the wells treated with MT1 supernatant only. When cultures to which IFNs were also added (final dilution of $1,000 \mathrm{U} / \mathrm{ml} / 5 \times 10^{5}$ cells) are taken into consideration, actual median cpm values of $\left[{ }^{3} \mathrm{H}\right] \mathrm{TdR}$ incorporation in the wells treated with IFN only were considered as 0 inhibition. $\ddagger$ Reduction in the $\left[{ }^{3} \mathrm{H}\right] \mathrm{TdR}$ incorporation by cells treated with IFNs, as compared with that in cultures treated with medium only, is expressed as a percentage and given in parentheses. 

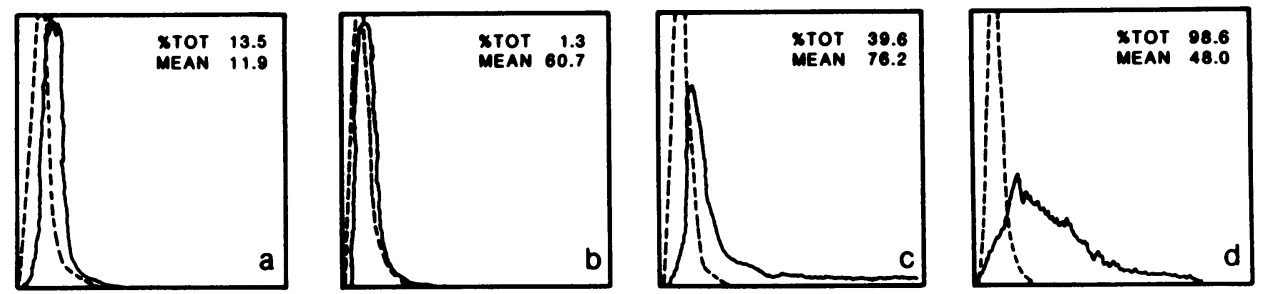

Figure 1. Cell sorter analysis of ML3 cells not treated $(a)$, treated with $10 \%$ CIL for $3 \mathrm{~d}(b)$, and treated with IFN $\gamma$ for $3 \mathrm{~d}(c)$ was done using FITC-labeled S1.19/9, a monomorphic anti-HLA-DR monoclonal antibody. In $d$, the positive control was obtained using anti-HLA-A,B,C monoclonal antibody S1.34/28. The

negative control is indicated on each graph with a dotted line. Percentages of cells expressing the antigen detected by the indicated antibody are given as a percentage of the total cell number (\% TOT). The mean fluorescence intensity, in arbitrary units ranging from 1 to 200 , is also quoted. The ML3 cell population varies in its $\mathrm{DR}^{+}$percentage depending on the day of harvesting and on the concentration of cell culture. These graphs were obtained by testing at different steps the cell population used for the experiment described in Table III.

$43 \%$, or 68 and $49 \%$ vs. 89 and $78 \%$ at the respective day and dilution tested). In parallel experiments under the same conditions, IFN $\alpha$ reduced ML3 growth rate (percent inhibition given in parentheses), but failed to enhance CIL activity significantly (Table III).

Inhibitory effect of CIL on human MHC-allogeneic MLR. To confirm that the inhibitory effect of CIL was dependent upon the presence of DR antigens or DR-associated structures on the target cell surface and to determine the role, if any, of CIL in regulating the immune response, we turned to experiments involving MHC-allogeneic MLRs. The effect of CIL treatment on proliferative responses in various human MLR combinations is shown in Fig. 2. The peak of the reaction was between days 5 and 7 , depending on the combination of responder and stimulator. Negative controls were MLRs using irradiated stimulators and responders from the same donor. In parallel, the same combinations of cells used for the positive control were seeded in the presence of $10 \% \mathrm{MT} 1$ supernatant. The $\left[{ }^{3} \mathrm{H}\right] \mathrm{TdR}$ incorporation of the responder cells treated with the factor was consistently lower than that of the negative control. Titration experiments showed that CIL dilutions as low as $0.15-0.01 \%$ were still able to block MLRs (Fig. 3). In this respect, the CIL factor was apparently more effective for the $A$ anti- $C^{\prime}$ and $B$ anti- $C^{\prime}$ responses at lower dosages than for the $C$ anti- $A^{\prime}$ or $C$ anti- $B^{\prime}$ MLRs. The sensitivity, however, did not correlate with any polymorphic DR phenotype, as ascertained in titration experiments done using other donors (not shown). To determine whether the activity of CIL was directed primarily to the stimulator or the responder cell population in the mixed reaction, we pretreated responders and irradiated stimulators with the MT1 supernatant ( $10 \%$ final concentration) independently for $3 \mathrm{~h}$ at $4^{\circ} \mathrm{C}$, washed them in cold buffer, and then seeded them for the assay. Results from three sets of MLRs (Fig. 4) indicate that CIL activity is much more effective when stimulator cells are preincubated with the supernatant than when responders are preincubated. Further, experiments in which CIL was added to the MLRs on different days of culture showed that CIL-inhibiting activity was efficient only during the first $24-48 \mathrm{~h}$ of the alloreaction; addition after this time resulted in no inhibition even when MT1 supernatant was used at a $10 \%$ final dilution (Fig. 5).

Inhibitory effect of CIL on murine MLR across full MHC barrier. Analogous results were obtained when CIL activity was tested in murine MLRs. In a typical experiment (Fig. 6), CBA $\left(\mathrm{H}-2^{\mathrm{k}}\right)$ TDL were incubated with (B6xCBA)F1 (H-2 $\left.2^{\text {bxk }}\right)$ irradiated stimulator spleen cells either with or without MT1 supernatant at a $1 \%$ final dilution. $\left[{ }^{3} \mathrm{H}\right] \mathrm{TdR}$ incorporation was assayed on days 3-5 of culture. The peak response was obtained on day 4 of the semi-allogeneic anti-F1 culture, whereas the same response was markedly inhibited in the presence of CIL. On all days tested, the level of incorporation for the suppressed group did not exceed the background levels of controls stimulated with syngeneic irradiated CBA cells. Further studies with CIL in murine MLR cultures paralleled the findings in the human system (Figs. 3 and 4), i.e., supernatant used at a $0.01 \%$ dilution was still inhibitory, and preincubation of stimulators and not responders with the factor was sufficient to suppress the alloreactive response (not shown).

CBA responses in a 4-d MLR directed against a panel of irradiated stimulator spleen cells from strains expressing different H-2 haplotypes (e.g., H-2 $2^{\text {b,d,s,t4}}$ ) were all significantly inhibited by the presence of MT1 supernatant in the cultures (Fig. 7). This apparent non-Ia-restricted activity of CIL paralleled the findings in human MLRs (Figs. 2-5). In addition, an assay to test the temporal requirements for CIL in culture indicated that its presence was critical at the early stages of the alloresponse (0-48 h), after which no inhibition could be induced (in the 4-d CBA MLR response) (Fig. 8).

Effect of anti-DR monoclonal antibody on human MLRs and on human cell lines treated with CIL. Further evidence that the DR molecule serves as a receptor for CIL, a notion suggested by the IFNs as well as by the MLR experiments, was obtained in analysis using mouse monoclonal anti-DR antibodies to prevent CIL activity. Whereas anti-DR antibodies could not be used to inhibit CIL activity in MLRs because they themselves block the reaction, they were successfully used to reduce CIL inhibition of growth activity directed against sensitive cell lines. The results in Table IV show that monomorphic anti-DR monoclonal antibodies parallel the action of CIL obtained by gel-filtration on MLRs in a 6-d kinetics experiment, while in Table $\mathrm{V}$, results of a typical experiment are shown in which three anti-DR monoclonal antibodies (the monomorphic S1.19/ 9, B33.1, and the polymorphic E3.15/4) did not inhibit the growth of Raji cells but did drastically reduce CIL activity on the cells. The same amount of the S1.34/28 anti-HLA-A, -B, and $-\mathrm{C}$ monomorphic monoclonal antibody did not inhibit cell growth or block the inhibitory activity of CIL. Sensitivity of the cells to CIL also varied in this type of experiment, depending on the particular cell line, without any polymorphic DR antigen correlation. On the other hand, binding of monoclonal anti-DR antibodies, ${ }^{125} \mathrm{I}$ directly labeled, to the same cell lines were not blocked by CIL even when MT1 supernatant was used at a $50 \%$ final concentration and antibody dilution was $0.08 \mathrm{ng} / 150 \mu \mathrm{l}$ per $1 \times 10^{6}$ target cells. One example is given in Table VI. 


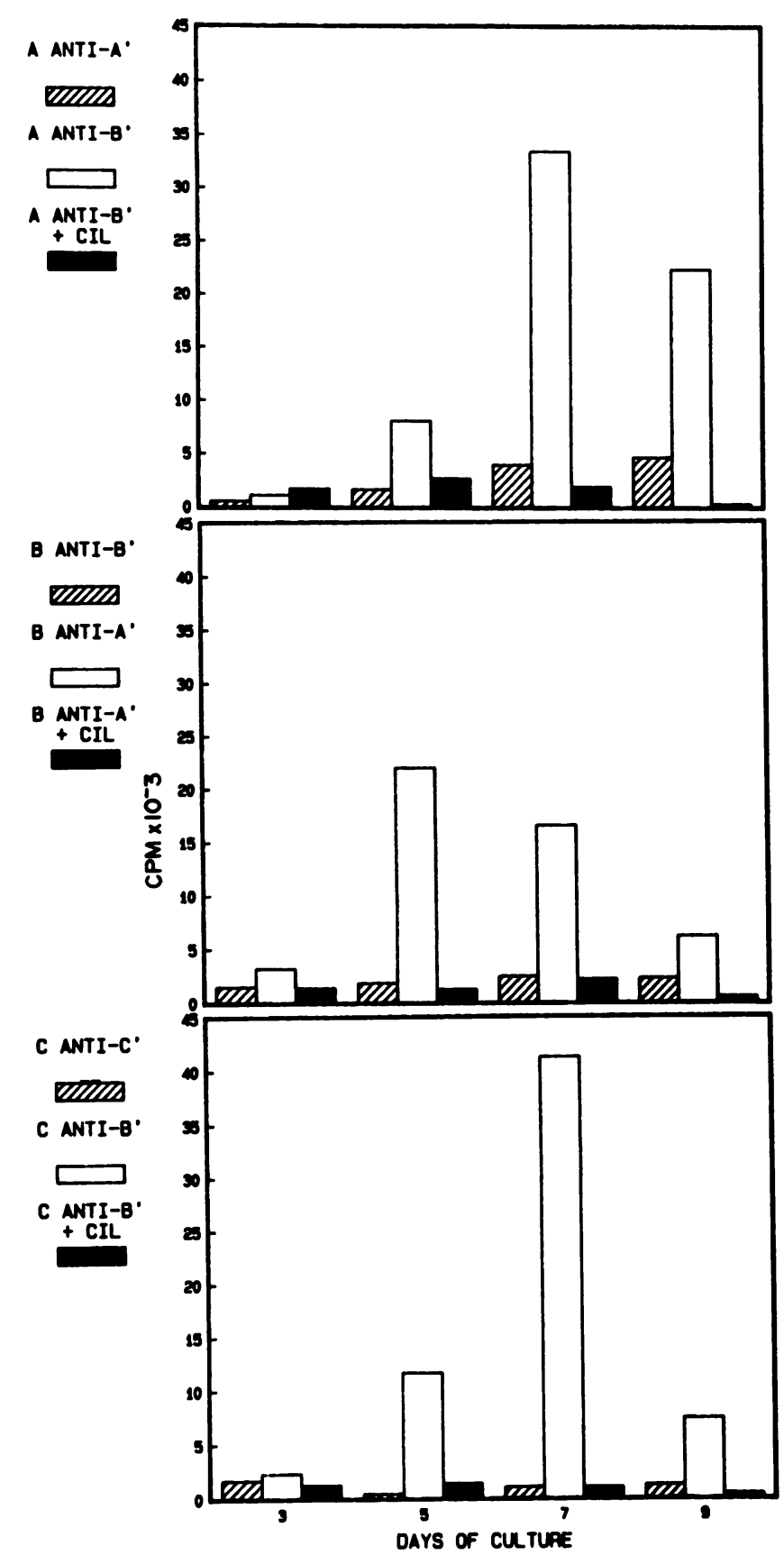

Figure 2. Inhibitory effect of CIL on human MHC-allogeneic MLR. MLR experiments were carried out using $10^{5}$ cells/well as responders (A, B, and C) vs. $2 \times 10^{5} \gamma$-irradiated cells/well as stimulators ( $\mathrm{A}^{\prime}, \mathrm{B}^{\prime}$, and $C^{\prime}$ ) in $0.2 \mathrm{ml}$ RPMI $1640+10 \%$ responder autologous serum. Cells were harvested on the respective day of culture. $\left[{ }^{3} \mathrm{H}\right] \mathrm{TdR}$ incorporation (median counts per minute [cpm] of triplicates) was determined in a $12-\mathrm{h}$ assay. MT1 supernatant was added at day 0 , at a final dilution of $10 \%$. Donor A: HLA-A 26 (10), W33; B8, W45 (12); DR1, W6. Donor B: HLA-A W32; BW44 (12); DR 3,5. Donor C: HLA-A 1,25 (10); B8,18; DR 1,2.

\section{Discussion}

The present results demonstrate that the expression of Ia-like molecules on the surface of the target cells is a requirement for the inhibitory activity of the human T cell-secreted factor CIL.

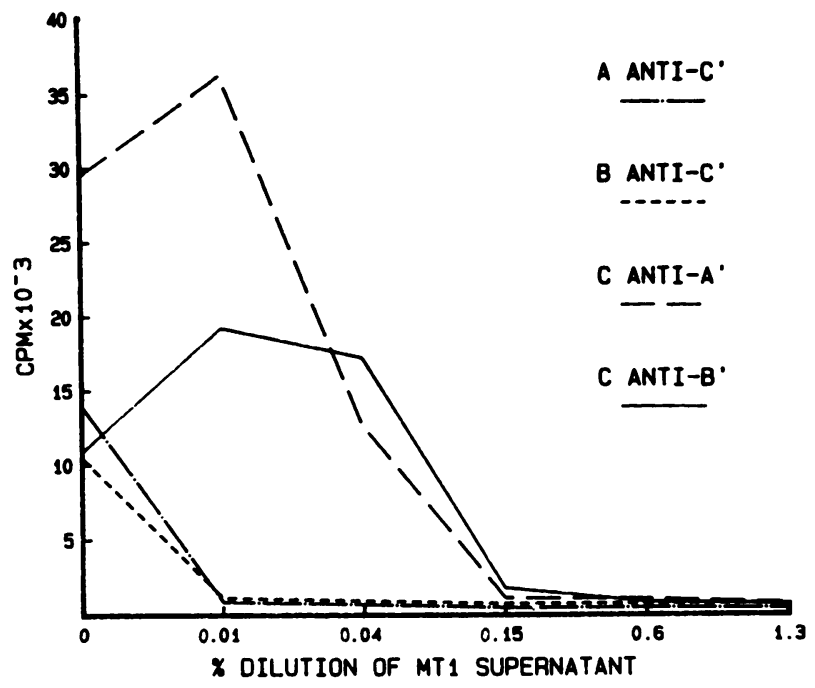

Figure 3. Inhibitory effect of CIL on human MLR: titration of MT1 supernatant. MLR culture conditions are as described in the legend to Fig. 2. $\left[{ }^{3} \mathrm{H}\right] \mathrm{TdR}$ incorporation (median cpm of triplicates) was determined in 12-h assay. MT1 supernatant was added at day 0 in MLR harvested after day 6 of culture. Incorporation by background control cultures, set up using irradiated stimulators and responders from the same donor, were $349 \mathrm{cpm}\left(A\right.$ anti- $\left.A^{\prime}\right), 675 \mathrm{cpm}\left(B\right.$ anti- $\left.B^{\prime}\right)$, and $2,712 \mathrm{cpm}\left(C\right.$ anti- $\left.C^{\prime}\right)$. A, B, and $C$, responders; $A^{\prime}, B^{\prime}, C^{\prime}$, irradiated stimulators. Donor A: HLA-A 2, 11; B w44, w62 Bw4w6; Cw3; DR 1. Donor B: HLA-A 1,2; B8, w44; DR 2,3. Donor C: HLA-A 2,11; B 7; DR 2,5.

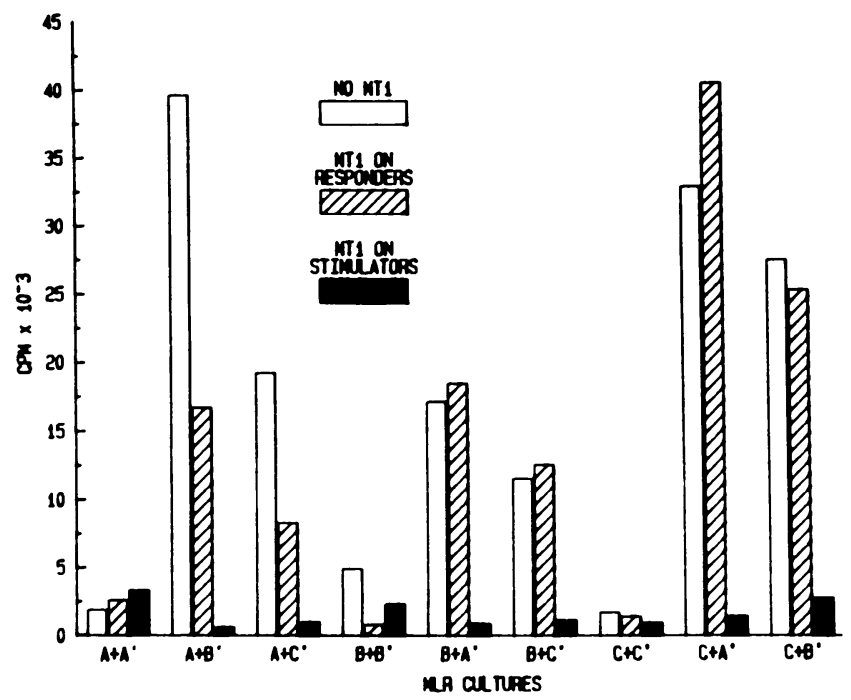

Figure 4. Effect of MT1 supernatant on independently treated responders or stimulators. MLR experiments were done using $10^{5}$ cells/ well as responders (A, B, and C) vs. $2 \times 10^{5} \gamma$-irradiated cells/well as stimulators $\left(\mathrm{A}^{\prime}, \mathrm{B}^{\prime}\right.$, and $\left.\mathrm{C}^{\prime}\right)$ in $0.2 \mathrm{ml}$ RPMI $1640+10 \%$ responder autologous serum. In the positive controls no MT1 supernatant was used (white bars). Responders (hatched bars) or stimulators (shaded bars) were treated independently for $3 \mathrm{~h}$ with $10 \%$ MT1 supernatant, washed three times, and seeded for MLR. Background control cultures were set up using irradiated stimulators and responders from the same donor. Cells were harvested on day 6 of culture. Same donors as in Fig. 3. $\left[{ }^{3} \mathrm{H}\right] \mathrm{TdR}$ incorporation (median cpm of triplicates) was determined in a $12-\mathrm{h}$ assay. 


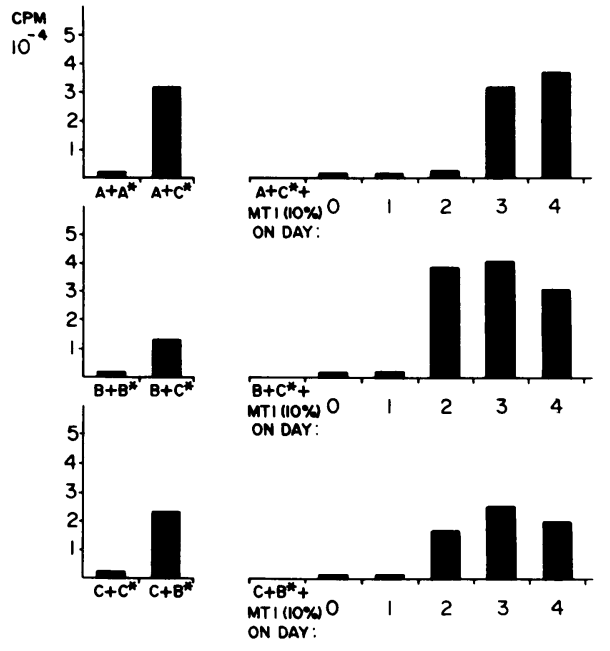

Figure 5. Inhibitory effect of MT1 supernatant added to human MLR at different days of culture. MLR experiments were performed using $10^{5}$ cells/well as responders (A, B, and $\mathrm{C}$ ) vs. $2 \times 10^{5} \gamma$-irradiated cells/well as stimulators $\left(A^{*}, B^{*}, C^{*}\right)$ in $0.2 \mathrm{ml}$ RPMI $1640+10 \%$ responder autologous serum. Cells were harvested on day 6 of culture. Same donors as in Fig. 2. [ $\left.{ }^{3} \mathrm{H}\right] \mathrm{TdR}$ incorporation (median cpm of triplicates) was determined in a 12-h assay.

This correlation between DR expression and CIL sensitivity was suggested in our previous studies (20) and seems to be the only feature CIL shows in common with other factors proven to be active in limiting the in vitro growth of Ia-positive bone marrow progenitor cells. The inhibitory pattern on myeloid progenitors, as well as the biochemical characteristics, are in fact unlike those shown by lactoferrin (85,000-100,000 mol wt), for example, which indirectly affects the growth of CFU-GM by inhibiting

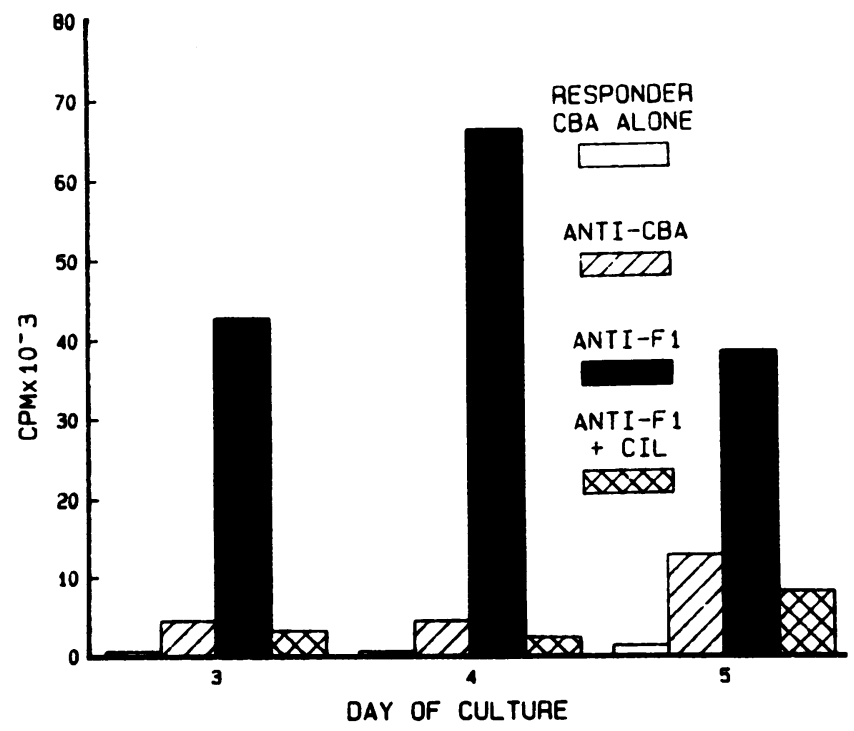

Figure 6. Inhibitory effect of MT1 supernatant on MHC-semiallogeneic murine MLR. The inhibition of a MHC-semiallogeneic murine MLR (CBA anti-[B6CB]F1) was tested by co-incubating the cells with a $10 \%$ final dilution of MT1 supernatant containing the CIL factor. The $y$-axis represents the level of $\left[{ }^{3} \mathrm{H}\right] \mathrm{TdR}$ incorporation (mean cpm of four replicates) of cultures harvested on days 3-5. The murine MLRs were set up as described in Methods.

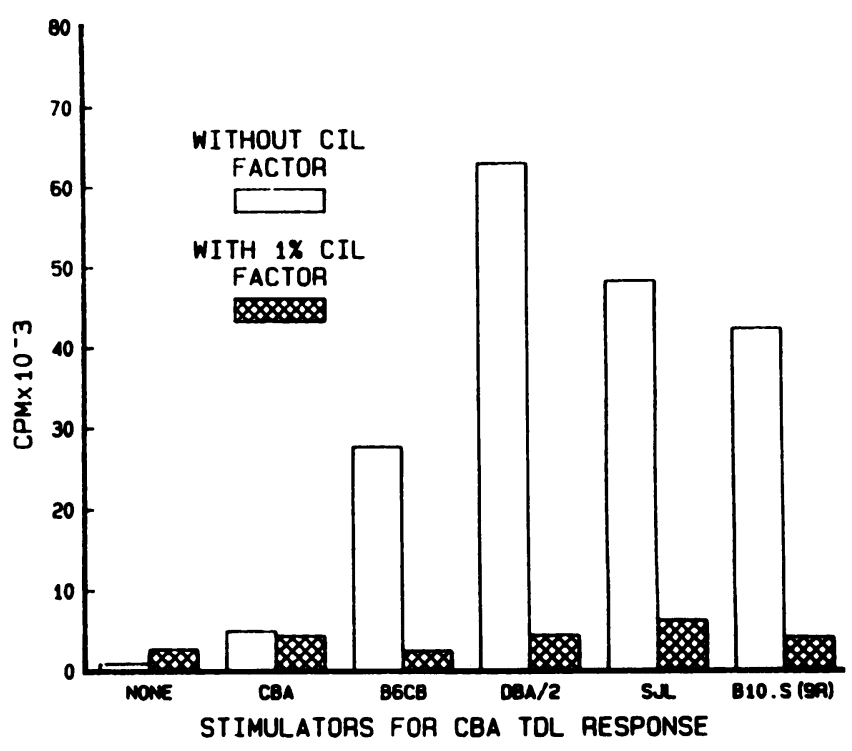

Figure 7. Nonpolymorphic inhibitory effect of CIL in murine MLRs. Nonpolymorphic inhibitory activity of the CIL factor was seen in murine MLRs using CBA responder cells that were stimulated with irradiated allogeneic spleen cells of different $\mathbf{H}-2$ haplotypes and cultured with or without MT1 supernatant at a $1 \%$ final dilution. The level of $\left[{ }^{3} \mathrm{H}\right] \mathrm{TdR}$ incorporation (mean cpm of four replicates) is for cultures harvested on day 4 , the peak of the response.

the production of CSF by monocytes (6). This precludes experimental demonstrations of its effects on cultures maximally stimulated by an exogenous CSF, such as GCT-conditioned medium (31), which was the way CIL was originally tested (20). Acidic isoferritin (450,000-500,000 mol wt), on the other hand, inhibits colony formation by direct action on CFU-GM, as does

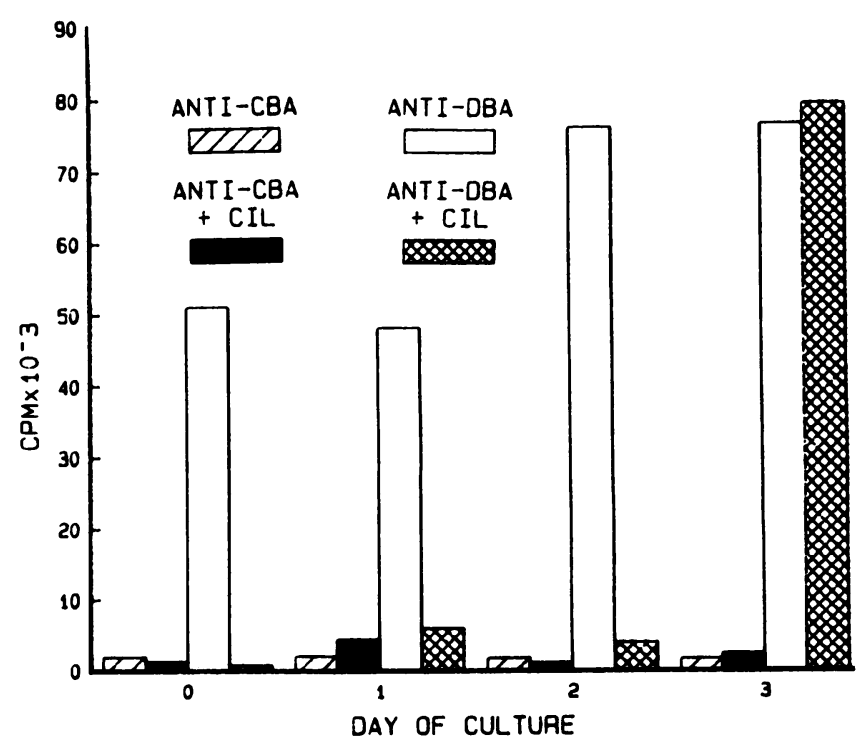

Figure 8. Inhibitory effect of MT1 supernatant added to the murine MLR on different days of culture. The effect of CIL factor upon a murine MHC-allogeneic MLR (CBA anti-DBA) was tested by adding MT1 supernatant ( $1 \%$ final dilution) to the cultures at different days. All cells were harvested on day 4 of culture and $\left[{ }^{3} \mathrm{H}\right] \mathrm{TdR}$ incorporation (mean cpm of four replicates) evaluated in a 12-h assay. 
Table IV. Inhibitory Effect of MT1 Supernatant on MLR in Comparison with the Effect of Anti-DR Monoclonal Antibodies

\begin{tabular}{|c|c|c|c|c|c|c|c|c|}
\hline \multirow[b]{2}{*}{ Cells } & \multirow{2}{*}{\multicolumn{2}{|c|}{ Cultured in presence of }} & \multicolumn{6}{|c|}{$\left[{ }^{3} \mathrm{H}\right] \mathrm{TdR}$ incorporation $\left(\mathrm{cpm} \mathrm{10^{-3 } )}\right.$ on day 6 factor and antibodies added on day: } \\
\hline & & & 1 & 2 & 3 & 4 & 5 & 6 \\
\hline$A+A^{\prime}$ & Medium & & 4.3 & 5.3 & 6.3 & 6.5 & 4.7 & 13.1 \\
\hline \multirow[t]{8}{*}{$A+B^{\prime}$} & Medium & & 90.6 & 131.4 & 71.8 & 116.7 & 114.5 & 99.1 \\
\hline & MTI SN & $0.1 \%$ & 8.0 & 9.3 & 17.3 & 36.4 & 65.7 & 144.1 \\
\hline & $\mathrm{S} 1.19 / 9$ & $5 \mu \mathrm{g} / 100 \mu \mathrm{l}$ & 1.2 & 3.9 & 6.2 & 14.6 & 32.4 & 33.3 \\
\hline & & $0.5 \mu \mathrm{g} / 100 \mu \mathrm{l}$ & 95.6 & 85.3 & 97.9 & 95.7 & 116.3 & 102.8 \\
\hline & B33.1 & $5 \mu \mathrm{g} / 100 \mu \mathrm{l}$ & 16.1 & 41.9 & 97.2 & 111.7 & 122.4 & 98.8 \\
\hline & & $0.5 \mu \mathrm{g} / 100 \mu \mathrm{l}$ & 20.1 & 52.3 & 90.6 & 96.3 & 99.6 & 80.5 \\
\hline & S1.34/28 & $5 \mu \mathrm{g} / 100 \mu \mathrm{l}$ & 95.5 & - & 127.8 & 132.2 & 116.1 & 78.8 \\
\hline & & $0.5 \mu \mathrm{g} / 100 \mu \mathrm{l}$ & 122.2 & - & 129.2 & 109.2 & 118.6 & 112.1 \\
\hline
\end{tabular}

MLR experiments were done under the same conditions as described in Fig. 2. Affinity-purified monoclonal antibodies or MT1 supernatant gel filtered and pooled (see Methods) were added on the respective days of culture. $\left[{ }^{3} \mathrm{H}\right] \mathrm{TdR}$ incorporation (median cpm of triplicates) in a $12-\mathrm{h}$ assay was determined after $6 \mathrm{~d}$ of culture. Donor A: HLA-A 1,2; B 8,14 Bw6; DR 1,3. Donor B: HLA-A 1,3; B 7,8; DR 2,3.

CIL. However, even when high concentrations of acidic isoferritin are used, colony formation still reaches $50 \%$ of the control values, whereas CIL blocks CFU-GM completely. We also demonstrated (20) that CIL could be distinguished from IFN $(15,000$ $60,000 \mathrm{~mol} w \mathrm{w})$, which at high concentrations has an inhibitory effect on CFU-GM colony formation (32), since even undiluted CIL fails to protect in vitro human fetal skin fibroblasts or bovine brain fibroblasts from the cytopathic effect of vesicular stomatitis virus. The inability of the MT1 supernatant to induce differentiation markers in HL-60 cells, even if used at a $50 \%$ final concentration, distinguishes CIL activity from the differentiationinducing factor $(35,000-55,000 \mathrm{~mol} \mathrm{wt})(33)$.

In spite of these differences, however, CIL, like many of the quoted factors, needs the la-like molecule on the target cell to be active. Here we show that only the growth of $\mathrm{DR}^{+}$cell lines is blocked by $\mathrm{CIL}$, and all the $\mathrm{DR}^{+}$cell lines cease dividing after $2 \mathrm{~d}$ in culture in the presence of the factor, as determined by $\left[{ }^{3} \mathrm{H}\right] \mathrm{TdR}$ incorporation. These cell lines differed somewhat in their sensitivity to the factor, i.e., some of the lines were dead after just a few days of culture, whereas others survived for 10 $\mathrm{d}$ before dying. Cell lines, such as ML3, in which DR antigen is expressed on only a limited number of cells (5-25\% of the total), are sensitive to CIL activity only during the first few days of culture, possibly because of a CIL-induced modulation of surface DR antigen. The remaining population of living cells, in which $\mathrm{DR}^{+}$cells are no longer detectable, continue growing at the rate of untreated cells. This observation bears on the IFN experiments, in which the enhancement of CIL sensitivity by IFN $\gamma$ can best be seen on days 4 and 5 of the assay, when, in the control, ML3 cells that survive CIL treatment are growing at their normal rate. The high percentage of inhibition in CILtreated ML 3 cells after $3 \mathrm{~d}$ of IFN $\gamma$ exposure followed by removal of this agent, even discounting the cytostatic effect of IFN $\gamma$ in calculating inhibition, suggested that increased DR expression on the cell surface accounted for increased CIL sensitivity. IFN $\alpha$, which acts synergistically with other lymphotoxins (34), but which does not increase DR expression at the cell surface (35), did not enhance CIL-mediated cell growth inhibition at all, although it did inhibit cell proliferation to the same extent that IFN $\gamma$ does. We can thus rule out the possibility that IFN $\gamma$ is increasing CIL inhibitory activity on target cells solely by virtue of inhibiting cell proliferation or synchronizing ML3 cells at a specific point of their cell cycle. Koeffler et al. (36) demonstrate that the increase of DR antigens and the appearance of cell differentiation antigens on HL-60 cells, for example, are two uncoupled events mediated by IFN $\gamma$ and that HLA-DR antigen expression increases after IFN $\gamma$ exposition on nondividing monocytes as well. We believe that these findings are supportive of the hypothesis that IFN $\gamma$-mediated CIL enhancement is related to HLA-DR increase, independent of MT3 cell cycle and IFN $\gamma$ cytostatic effect. Also supportive is the fact that CIL enhancement becomes evident on unsynchronized ML3 cells before the cytostatic effect does, and when DR expression is already present on $39 \%$ of the target cells.

MLR assays, which depend upon the $\mathrm{T}$ cell recognition of allogeneic Ia antigens, indicated that the activity of this factor is directed mainly toward the stimulator cells in the reaction and that the inhibition requires that the factor be present in the first $48 \mathrm{~h}$ of the reaction when "recognition" occurs. This is consistent with the notion of CIL-Ia-like molecule interaction. The MLR experiments and the inhibition tests using sensitive cell lines that differ in HLA-DR typing indicated that the factor does not recognize a polymorphic DR determinant, i.e., this inhibitory activity is not restricted to any particular DR phenotype. CIL also did not appear to be species-specific or MHCrestricted, as shown by its activity in murine MLRs.

The variable sensitivity of cells from different donors to the activity of the factor, as indicated in titration experiments and in growth inhibition tests with different target cell lines (Table II and Fig. 3), might rest in the variable amounts of DR antigen on the surface of different cells. No correlation has been observed with polymorphic DR determinants, and variable affinities of CIL for different DR antigens, therefore, cannot be considered. CIL affinity for its receptor allowed the absorption of CIL activity from the MT1 supernatant using $\mathrm{DR}^{+}$cell lines, bringing the effective final dilution on MLR tests from 0.01 to $0.1 \%$. On the other hand, it has not yet been possible to immunoprecipitate an $85-\mathrm{kD}$ protein (corresponding to CIL as determined by gel filtration [20]) in SDS PAGE, using mouse anti-DR monoclonal antibodies and solubilized membranes of the same $\mathrm{Ia}^{+}$cell lines treated with $\left[{ }^{35} \mathrm{~S}\right]$ methionine-labeled CIL. Proof that the Ia molecule is the receptor for an $85-\mathrm{kD}$ protein awaits the co-precip- 
Table V. Effect of Anti-DR Monoclonal Antibody on a Human Cell Line (Raji) Treated with MT1 Supernatant

\begin{tabular}{|c|c|c|c|c|c|}
\hline \multirow{2}{*}{$\begin{array}{l}5 \times 10^{3} \text { cells } \\
\text { cultured } \\
\text { in presence of: }\end{array}$} & \multicolumn{5}{|c|}{ Percentage of inhibition of $\left[{ }^{3} \mathrm{H}\right] \mathrm{TdR}$ incorporation on day 3 in presence of: } \\
\hline & Medium & S1.19/9 & B33.1 & E3.15/4 & S1.34/28 \\
\hline Medium & $0(28,315)$ & $0(27,053)$ & $0(33,986)$ & $0(29,471)$ & $0(26,401)$ \\
\hline MT1 SN $1 \%$ & 54 & 9 & 28 & 31 & 58 \\
\hline $0.1 \%$ & 29 & 0 & 22 & 1 & 53 \\
\hline $0.01 \%$ & 15 & 0 & 0 & 0 & 32 \\
\hline $0.001 \%$ & 6 & 0 & 0 & 0 & 1 \\
\hline
\end{tabular}

Raji cells were cultured and monitored as described in the Table III legend. Anti-HLA-DR monoclonal antibodies S1.19/9, B33.1 and E3.15/4 $(5 \mu \mathrm{g} / 100 \mu \mathrm{l})$, or anti-HLA-A, -B, and -C, monoclonal antibody S1.34/28 was added to the cultures together with appropriate dilutions of MT1 supernatant. $\left[{ }^{3} \mathrm{H}\right] \mathrm{TdR}$ incorporation by cells supplemented with $22 \mu \mathrm{l} /$ well of plain medium or with monoclonal antibodies only was considered maximum uptake (0\% inhibition). Median cpm values are given in parentheses. HLA typing of the Raji cell line is given in Table II.

itation of labeled CIL cross-linked to cell membrane receptors using anti-DR monoclonal antibodies.

Exposure to the factor for $3 \mathrm{~h}$ at $4^{\circ} \mathrm{C}$ was sufficient to block stimulator activity in MLRs even after washing. The partial inhibition seen on some independently treated responders (e.g., responder $A$ in Fig. 4) might be due to absorption of the factor by the $\mathrm{DR}^{+}$cells present in the responder population and subsequent release during $6 \mathrm{~d}$ of the MLR.

Evidence that the DR molecule can be the receptor for CIL also came from the inhibition experiment on sensitive cell lines using mouse anti-DR monoclonal antibodies. The results showed that the factor did not block the binding of anti-DR monoclonal antibodies to a $\mathrm{DR}^{+}$cell target, although these antibodies completely abrogated the factor activity on the same target cells (Tables V and VI). This can be explained by possible differences in affinity between factor and antibodies for the DR antigen, or differences in the quantity necessary to achieve the effect of the factor vs. the monoclonal antibodies. Since the inhibition cannot

Table VI. Effect of Anti-DR Monoclonal Antibody on a Human Cell Line (Raji) Treated with MT1 Supernatant

\begin{tabular}{|c|c|c|c|c|}
\hline \multirow{3}{*}{$\begin{array}{l}\text { Antibody } \\
\text { dilution }\end{array}$} & \multicolumn{4}{|c|}{${ }^{125}$ I-Antibody uptake by $10^{6}$ cells treated with: } \\
\hline & \multicolumn{2}{|l|}{ B33.1 } & \multicolumn{2}{|l|}{ S1.34/28 } \\
\hline & Medium & MTI SN & Medium & MTI SN \\
\hline$n g$ & $c p m \times 10^{-3}$ & $c p m \times 10^{-3}$ & $c p m \times 10^{-3}$ & $c p m \times 10^{-3}$ \\
\hline 2.50 & 10.2 & 12.3 & 12.9 & 14.9 \\
\hline 1.25 & 5.7 & 6.9 & 6.9 & 8.4 \\
\hline 0.63 & 2.9 & 3.5 & 3.7 & 4.3 \\
\hline 0.31 & 1.4 & 1.7 & 1.9 & 2.3 \\
\hline 0.16 & 0.9 & 0.9 & 1.0 & 1.2 \\
\hline 0.08 & 0.4 & 0.5 & 0.6 & 0.7 \\
\hline
\end{tabular}

Raji cells were tested against ${ }^{125}$ I directly labeled monoclonal antibodies B33.1, anti-DR, and S1.34/28, anti-HLA-A, -B, and -C as a control. The input was $50,000 \mathrm{cpm} /$ well in the first dilution tested, corresponding to $2.50 \mathrm{ng}$ antibody/well. Antibody dilutions (one to two) were added to the other wells in both (with or without MT1 SN) combinations. Median cpm values are from triplicates; background of 50 cpm has been subtracted. MT1 supernatant was used at a fixed final concentration of $50 \%$; culture medium was used in comparison. be proven to be reciprocal (i.e., antibody blocked by the factor as well as the factor blocked by antibody) even when limiting quantities of the antibody are used and the MT1 supernatant concentration is increased to $50 \%$, a third hypothesis must also be taken into consideration. CIL may act on its own receptor, independent of the DR molecule but interacting somehow with it at the cell surface. However, it is interesting to note that even if the same type of inhibition is displayed by anti-DR monoclonal antibodies and by the factor in MLRs, suggesting that this DR molecule-mediated cell activity can be regulated by both agents, $10^{6}$ mouse hybrid cells can secrete $50 \mu \mathrm{g}$ of antibody into their supernatant in $24 \mathrm{~h}$, and that this supernatant is effective only if diluted no more than 1:1 (Table IV). In comparison, $10^{6} \mathrm{MT} 1$ cells secrete, in the same period of time, sufficient CIL to render the supernatant effective at a 1:100,000 dilution on the same target.

Because the factor also acts on mouse target cells, a convenient in vivo system exists for investigations of the physiological significance of the factor in both hematopoiesis and generation of the immune response. The activity of CIL on the bone marrow cells of normal mice, as well as the potential role of this factor in preventing graft-vs.-host reactions, are currently under investigation. These experiments should confirm, for instance, the etiology of severe aplastic anemia, hypothesized to be the outcome of an unbalanced activity due to a subpopulation of $\mathrm{T}$ lymphocytes that blocks the differentiation of the hemopoietic precursors via an inhibitory secreted factor $(37,38)$.

In the MLR experiments, as in the CFU-GM and BFU-E assays, it is the fraction corresponding to $85 \mathrm{kD}$ of the gel filtered MT1 SN that expresses inhibitory activity. The fact that both activities are contained in the same fraction allows us to postulate that it is actually the same factor that seems to act both on hematopoietic cell targets and on cells of the immune response. Purified material will provide a definite answer if CIL is really the link between the two systems using a common "receptor," the Ia-like molecule.

\section{Acknowledgments}

We thank Jack Bennink and Giorgio Trinchieri for valuable discussion and suggestions and for reading the manuscript, and Chester Zmijewski and Bill Sullivan for HLA typing.

This work is supported by National Institutes of Health grants CA10815, CA-37932, and NS-11036. 


\section{References}

1. Parker, J. W., and D. Metcalf. 1974. Production of colony stimulating factor in mitogen-stimulated lymphocyte cultures. J. Immunol. 112:502-507.

2. Iscove, N. N., J. S. Senn, J. E. Till, and E. A. McCulloch. 1971 Colony formation by normal and leukemic human marrow cells in culture: effect of conditioned medium from human leukocytes. Blood. $37: 1-7$.

3. Johnson, G. R., C. Dresch, and D. Metcalf. 1977. Heterogeneity in human neutrophil, macrophage, and eosinophil progenitor cells demonstrated by velocity sedimentation separation. Blood. 50:823-831.

4. Tepperman, A. D., J. E. Curtis, and E. A. McCulloch. 1974. Erythropoietic colonies in cultures of human marrow. Blood. 44:659669.

5. Iscove, N. N., F. Sieber, and K. H. Winterhalter. 1974. Erythroid colony formation in cultures of mouse and human bone marrow: analysis of the requirement for erythropoietin by gel filtration and affinity chromatography on agarose-concanavalin A. J. Cell. Physiol. 83:309-314.

6. Broxmeyer, H. E., A. Shithyman, R. R. Eger, P. A. Meyers, and M. de Sousa. 1978. Identification of lactoferrin as the granulocyte-derived inhibitor of colony stimulating activity production. J. Exp. Med. 148:1052-1063.

7. Kurland, J., R. Bockman, H. E. Broxmeyer, and M. Moore. 1978. Limitation of excessive myelopoiesis by the intrinsic modulation of macrophage-derived prostaglandin E. Science (Wash. DC). 199:552-553.

8. Broxmeyer, H. E., T. Bognati, M. H. Dorner, and M. de Sousa 1981. Identification of leukemia-associated inhibitory activity as acidic isoferritus. J. Exp. Med. 153:1426-1444.

9. Broxmeyer, H. E., L. Lu, and J. Bognaki. 1983. Transferrin, derived from an OKT8-positive subpopulation of T lymphocytes, suppresses the production of granulocytic-macrophage colony stimulating factors from mitogen-activated T lymphocytes. Blood. 62:37-42.

10. Broxmeyer, H. E. 1979. Lactoferrin acts on Ia-like antigen-positive subpopulations of human monocytes to inhibit production of colony stimulating activity in vitro. J. Clin. Invest. 64:1717-1726.

11. Broxmeyer, H. E. 1982. Relationship of cell cycle expression of Ia-like antigenic determinants on normal and leukemia human granulocyte-macrophage progenitor cells to regulation in vitro by acidic isoferritins. J. Clin. Invest. 69:632-642.

12. Pelus, L. M. 1982. Association between colony-forming unitsgranulocyte macrophage expression of Ia-like (HLA-DR) antigen and control of granulocyte and macrophage production. A new role for prostaglandin E. J. Clin. Invest. 70:568-578.

13. Winchester, R. J., G. D. Ross, C. I. Jarowski, C. Y. Wang, J. Halper, and H. E. Broxmeyer. 1977. Expression of Ia-like antigen molecules on human granulocytes during early phases of differentiation. Proc. Natl. Acad. Sci. USA. 74:4012-4017.

14. Moore, M. A. S., H. E. Broxmeyer, A. P. C. Sheridan, P. A. Meyers, N. Jacobsen, and R. J. Winchester. 1980. Continuous human bone marrow culture: Ia antigen characterization of probable pluripotential stem cells. Blood. 55:682-691.

15. Torok-Storb, B., P. J. Martin, and J. A. Hansen. 1981. Regulation of in vitro erythropoiesis by normal $\mathrm{T}$ cells: evidence for two $\mathrm{T}$ cell subsets with opposing function. Blood. 58:171-177.

16. Torok-Storb, B., and J. A. Hansen. 1982. Modulation of in vitro BFU-E growth by normal Ia-positive T cells is restricted by HLA-DR. Nature (Lond.). 298:673-675.

17. Winchester, R. J., and H. G. Kunkel. 1979. The human Ia system. Adv. Immunol. 28:221-235.

18. Schreier, M. H., R. Tees, and A. A. Nordin. 1982. Establishment and characterization of helper $\mathrm{T}$ cell clones: their functional heterogeneity and effect on the B-cell responses to particulate, soluble and T-independent antigens. Lymphokines. 5:443-454.

19. Von Boehmer, H., W. Haas, G. Kohler, F. Merchers, and J. Zeuthen. 1982. T cell hybridomas. Curr. Top. Microbiol. Immunol. 100: $5-320$.
20. Trucco, M., G. Rovera, and D. Ferrero. 1984. A novel human lymphokine that inhibits hematopoietic progenitor cell proliferation. Nature (Lond.). 309:166-169.

21. Trucco, M., G. Garotta, J. W. Stocker, and R. Ceppellini. 1979. Murine monoclonal antibodies against HLA structures. Immunol. Rev 47:219-252.

22. Trucco, M., G. Galfre, M. DeMarchi, O. Varetto, and A. O. Carbonara. 1977. "tb 9," a new HLA-D specificity defined by two homozygous typing cells. Tissue Antigens. 10:343-344.

23. Korngold, R., and J. Sprent. 1980. Negative selection of T-cells causing lethal graft vs. host disease across minor histocompatibility barriers. Role of the H-2 complex. J. Exp. Med. 151:1114-1125.

24. Trucco, M., J. W. Stocker, and R. Ceppellini. 1978. Monoclonal antibodies against human lymphocyte antigens. Nature (Lond.) 273:666-669.

25. Trucco, M., J. W. Stocker, and R. Ceppellini. 1978. Monoclonal antibodies to human lymphocyte membrane antigens. Curr. Top. Microbiol. Immunol. 81:66-70.

26. Ey, P. L., S. J. Prowse, and C. R. Henkin. 1978. Isolation of pure IgG1, IgG2a, and IgG2b immunoglobulin from mouse serum using protein A-Sepharose. Immunochemistry. 15:7429-7434.

27. Perussia, B., D. Acuto, C. Terhorst, J. Faust, R. Lazarus, V. Fanning, and G. Trinchieri. 1983. Human natural killer cells analyzed by B73.1, a monoclonal antibody blocking Fc receptor functions. J. Immunol. 130:2142-2150.

28. Trucco, M., and S. de Petris. 1981. Determination of equilibrium binding parameters of monoclonal antibodies specific for cell surface antigens. In Immunological Methods, Vol. 2. Academic Press, Inc., New York. 1-26.

29. Seabright, M. 1971. A rapid banding technique for human chromosomes. Lancet. I:1971-1975.

30. Santoli, D., M. K. Francis, and M. Trucco. 1981. Phenotypic and functional characterization of allospecific and nonspecific (NK- and $\mathrm{K}$-like) cytotoxic $\mathrm{T}$ lymphocytes generated in human mixed-lymphocyte cultures from non-cytotoxic precursors. Cell Immunol. 65:230-245.

31. Di Persio, J. F., J. K. Brennan, M. Lightman, C. N. Abboud, and F. H. Kirkpatrick. 1980. The fractionation, characterization, and subcellular localization of colony-stimulating activities released by the human monocyte-like cell line, GCT. Blood. 56:717-727.

32. Greenberg, P. L., and S. A. Mosny. 1977. Cytotoxic effects of interferon in vitro on granulocytic progenitor cells. Cancer Res. 37:17941799.

33. Olsson, J., T. Olofsson, and N. J. Mauritzon. 1981. Characterization of mononuclear blood cell-derived differentiation inducing factors for the human promyelocytic leukemia cell line HL-60. J. Natl. Cancer Inst. 67:1225-1231.

34. Stone-Wolff, D. S., Y. K. Yip, H. C. Kelker, J. Le, D. HenriksenDestefano, B. Y. Rubin, E. Rinderknecht, B. B. Aggarwal, and J. Vilcek. 1984. Interrelationships of human interferon-gamma with lymphotoxin and monocyte cytotoxin. J. Exp. Med. 159:828-831.

35. Basham, T., and T. Merigan. 1983. Recombinant gamma interferon increases HLA-DR synthesis and expression. J. Immunol. 130:1492-1499.

36. Koeffler, H. P., J. Ronyard, L. Yelton, R. Billing, and R. Bohman. 1984. $\gamma$ Interferon induces expression of HLA-D antigens on normal and leukemic human myeloid cells. Proc. Natl. Acad. Sci. USA. 81:4080-4084.

37. Bacigalupo, A., M. Podesta, M. C. Mingari, L. Moretta, M. T. Van Lint, and A. Marmont. 1980. Immune suppression of hematopoiesis in aplastic anemia: activity of T-gamma lymphocytes. J. Immunol. 125:1449-1456.

38. Bacigalupo, A., M. Podesta, M. C. Mingari, L. Moretta, G. Piaggio, M. T. Van Lint, A. Durando, and A. M. Marmont. 1981. Generation of CFUC/suppressor T cells in vitro: an experimental model for immunemediated marrow failure. Blood. 57:491-499.

39. Reinherz, E. L., and S. F. Schlossman. 1980. The differentiation and function of human T lymphocytes. Cell. 19:821-824. 